\title{
Emotional Responses to Reading in the First Grade - The "L.E.R. Cãofiante"* Project
}

\author{
Lourdes Mata ${ }^{1}$ \\ Maria José Mackaaij ${ }^{2}$ \\ Margarida Calado ${ }^{1,3}$ \\ ${ }^{1}$ Instituto Universitário in Lisbon \\ ${ }^{2}$ Instituto Universitário Municipality of Loulé \\ ${ }^{3}$ ISPA-Instituto Universitário, Lisbon
}

\begin{abstract}
The "L.E.R. Cãofiante"* project was implemented with first-grade pupils who took part in reading sessions animated by a librarian in partnership with her dogs. The goal was to evaluate the effect of this intervention on children's emotions regarding reading (enjoyment, anxiety, boredom). The participants were 80 children (47 in the Intervention Group (IG); 33 in the Comparison Group (CG)). Parents and teachers answered a questionnaire about children's involvement, and the children answered one about reading emotions. For data processing, repeated measures ANOVA was used along with content analysis of the answers to the questionnaires. The results showed different emotional profiles of children in the IG and the CG, mostly regarding enjoyment, which increased in the IG. Data from parents and teachers corroborated this conclusion, emphasising positive experiences which allowed an understanding of the role of dogs in children's enjoyment and interest in reading. Keywords: pleasure in reading; animal assisted therapy; dogs
\end{abstract}

\section{Resumo}

\section{Emoções Face à Leitura no $1^{\circ}$ Ano de Escolaridade - Projeto "L.E.R. Cãofiante"}

O projeto 'L.E.R. Cãofiante' foi implementado com alunos do $1^{\circ}$ ano que participaram em sessões de leitura na biblioteca, dinamizadas pela bibliotecária em parceria com os seus cães. O objetivo é apresentar a avaliação dessa intervenção nas emoções das crianças face à leitura (prazer, ansiedade, aborrecimento). Participaram 80 crianças (47 no projeto - GP; 33 no Grupo de Comparação - GC). Os encarregados de educação e as professoras responderam a um questionário sobre o envolvimento das crianças, e estas a um questionário de emoções. No tratamento de dados, usou-se a ANOVA para medidas repetidas e análise de conteúdo das respostas aos questionários. Os resultados evidenciaram perfis emocionais diferentes das crianças do GP e do GC essencialmente para o prazer que aumentou no GP. Os dados dos pais e professoras corroboraram essa conclusão realçando as vivências positivas que permitiram compreender o papel dos cães na satisfação e interesse dessas crianças pela leitura.

Palavras-chave: prazer na leitura, terapia assistida por animais, cães

\section{Resumen}

\section{Emociones hacia la Lectura en el $1^{\circ}$ Año de Escolaridad - Proyecto 'L.E.R. Cãofiante'}

El proyecto 'L.E.R. Cãofiante' fue implementado con alumnos de primer año que participaron en sesiones de lectura en la biblioteca, organizadas por el bibliotecario en compañía de sus perros. El objetivo de esta intervención fue evaluar las emociones de los niños con relación a la lectura (Placer, Ansiedad, Aburrimiento). Participaron 80 niños (47 en el proyecto - GP, y 33 en el grupo de comparación -GC). Los encargados de educación y las profesoras respondieron a un cuestionario sobre la participación de los niños, y éstos a un cuestionario de emociones. En el tratamiento de datos se utilizó ANOVA para medidas repetidas y un análisis de contenido de las respuestas de los cuestionarios. Los resultados evidenciaron perfiles emocionales diferentes en los niños del GP y del GC esencialmente para el Placer que aumentó en el GP. Los datos de los padres y profesoras corroboraron esta conclusión siendo resaltadas vivencias positivas que permitieron comprender el papel de los perros en la satisfacción e interés de estos niños por la lectura.

Palabras clave: Placer por lectura; Terapia Asistida por Animales; Perros

\section{Introduction}

In the educational context, learning to read and write takes on an important and often crucial weight in the success or failure of children. This learning process is conditioned by a series of individual and contextual variables, and is not always felt as easy, instead demanding commitment and effort, along with a set of diversified strategies in order to give a timely and adjusted response to the difficulties that arise (Froiland \& Oros, 2013; Scanlon, Anderson, \& Sweeney, 2017).

Children with reading difficulties very often lack confidence in their abilities, have limited access to interesting reading materials, have less reading opportunities in their environments and find less enjoyment or interest in reading (Jalongo, 2005). Animal Assisted Reading

*READ confident with a dog 
arises to help in dealing with these difficulties by creating a safe, affective and non-judgemental reading environment, through an animal that helps these children feel increasingly at ease, confident and joyful with reading (Jalongo, 2005; Shaw, 2013). This aspect of Animal Assisted Reading becomes even more important as we know that, in a learning context, emotions such as enjoyment, hope, pride, anger, anxiety or boredom are frequently present, very often in an intense manner, and that they have an important role in academic development (Pekrun, 2013, 2014).

The bond between humans and animals is a welldocumented phenomenon ever since humans started to domesticate animals (Turner, 2007). Studies have been published which show that contact with animals is healthy (e.g. Friesen \& Delisle, 2012; Mills \& Hall, 2014; Nepps, Stewart, \& Bruckno, 2014), that a dog's presence stimulates a friendly conversation, encourages dialogue and socialisation between people, and contributes to children's self-concept as well as to physiological well-being, for example by reducing blood pressure and anxiety levels (Nepps et al., 2014; Wilson \& Turner, 1998).

The American Veterinary Medical Association (AVMA) regards this human-animal bond as a mutually benefiting and dynamic relationship which is influenced by behaviours that are essential to the health and wellbeing of both (AVMA, 2016). These include such aspects as emotional, psychological and physical interactions between people, animals and the environment (AVMA, 2016; Fine \& Beck, 2010; Mills \& Hall, 2014).

Odendaal (2000) presented a study on the subject of human-animal interaction in which several physiological parameters in people and dogs were compared before and after an interaction. By comparing interactions with dogs and the reading of books, the results have shown that the interactions with animals were as relaxing and stress-relieving as the reading of a book, possibly even more beneficial because of the positive effects caused by rises in oxytocin, prolactin and $\beta$-Endorphin. Friesen (2009) gathered data from a series of varied studies which tried to identify the benefits for children resulting from the presence of and interaction with animals in diversified activities or situations (e.g. going to the doctor, reading aloud, the classroom). The benefits found were physiological as well emotional and social (e.g. a decrease in stress and heart rate, increased attention spans and cooperation in performing tasks, a more positive attitude).

More recent studies have obtained results along the same lines (Beetz, 2013; Beetz \& McCardle, 2017; Kirnan, Siminerio, \& Wong, 2016). In a recent publication, Beetz and McCardle (2017) highlighted situations in which children read while accompanied by and touching a dog, where increases in oxytocin, the hormone responsible for stress and fear reduction, have been observed. In a previous study, Beetz (2013) had already observed that, in classrooms where a dog had been present, children had shown more positive attitudes and emotions towards school. Along these lines are the results from a longitudinal study developed by Kirnan et al., (2016), where differences in terms of attitudes towards reading were evident throughout various educational levels, and significant gains were observed in reading performance among pupils in earlier grades. In Friesen and Deslile's (2012) analysis of various Animal Assisted Reading programmes, they propose some aspects that, according to them, can make a difference in terms of positive effects in skill acquisition as well as in children's affective relationship with books and reading. According to the authors, children feel comfortable, competent and important as a result of the interactions and skills they develop with the dog's support. At the same time, the design of the programmes must have an underlying holistic conception of the child and their learning process, regarding social, emotional and academic components as interconnected in the strategies and approaches developed. This way, safe, playful and supportive learning environments are obtained which provide children with real and meaningful experiences around literacy, facilitating positive learning and affective experiences (Friesen \& Deslile, 2012), which are essential for learning.

There has been some increase in the number of studies on the role of emotions in learning processes (Pekrun, 2014). According to Pekrun (2009, 2014), emotions are reactions to significant events and objects, functioning as a way to adapt to and prepare for different processes of perception, cognition and action, as they affect such aspects as retrieval from memory storage, social judgement, decision-making, problem-solving and creative thinking. Emotions are frequently differentiated between positive and negative, but beyond this aspect they can also be distinguished between activating (e.g. joy, pride, anger, anxiety) or deactivating (e.g. relief, relaxation, despair, boredom) (Pekrun, 2009, 2013, 2014), with different implications for behaviour.

In learning contexts, literature has demonstrated changes in the emotional states of subjects as their education progressed. In what concerns anxiety, Pekrun $(2009,2014)$ mentions that this emotion is low in the first years of education and substantially increases 
with academic progression. On the other hand, positive emotions such as enjoyment seem to decrease with educational progress, which is consistent with the decline in scores measuring interest and attitudes towards school (Pekrun, 2009, 2014). The importance of being attentive to this decline in positive emotions and increase in negative emotions comes from knowing that, today, enjoyment, hope and pride are positively correlated with interest, effort, the elaboration of learning material, self-regulation and academic achievement (Pekrun, 2009). On the other hand, boredom is negatively correlated with intrinsic as well as extrinsic motivation, and also with studying and performing tasks.

Fredrickson's (2003, 2004, 2013) broaden-andbuild theory reveals some important functions of positive emotions, arguing that these lead to better results through two types of distinct, but complementary, processes: broadening the subject's attention and resources and building new resources. Thus, this theory proposes that positive emotions amplify people's attention and the way they manage their cognitive and behavioural resources (Fredrickson, 2004, 2013). The experiencing of positive emotions leads to patterns of thinking which are more open to new information, more creative, more flexible and integrative (broaden). This way, spirals of emotional, mental and physical well-being are created which lead to better functioning (Fredrickson, 2003; Fredrickson \& Joiner, 2002, 2018). This broadening creates the conditions for reinforcing or building long-lasting social, intellectual, psychological and physical resources (build). Thus, when for example, children play or participate in social activities, they can at first be motivated by the enjoyment itself, but this will contribute to the development of various resources: physical (e.g. coordination, strength), psychological (e.g. personal goals, resilience), social (e.g. friendship, social skills) and intellectual (e.g. new information, problem-solving) (Fredrickson, 2003, 2004, 2013). These personal resources which result from positive emotional states are long-lasting, they persist beyond the moment which lead to their acquisition, because they lead to the subject's transformation, making one more resilient, socially integrated and healthy.

This theory allows us a new perspective on the adaptive role of positive emotions as well as on their long-lasting effect beyond the specific moment in which they are experienced. According to this theory, positive emotions thus become essential elements for good functioning and the well-being of subjects for different reasons, among which stand out the broadening of attention and thinking, the building of new personal resources, the increase of resilience and the potentiating of spirals of well-being (Fredrickson, 2004, 2013).

Taking into consideration the important role of emotions in learning contexts (Pekrun, 2009, 2013, 2014), the positive role that Animal Assisted Reading can have in the promotion of positive emotions and well-being (Beetz, 2013; Friesen \& Deslile, 2012; Kirnan et al., 2016) and the importance of positive emotions in cognitive, psychological and social resources (Fredrickson, 2004, 2013), this study tried to evaluate the impact of an AAR intervention with first-grade pupils in what concerns these children's emotional responses to reading.

\section{Method}

This investigation was designed in a quantitative, quasi-experimental manner, which considers an Intervention Group and a Comparison Group. Two evaluations were made, one at the beginning of the school year, the other at the end, in order to characterise the emotions associated with the reading moment in all the children.

\section{The "L.E.R. Cãofiante" Project}

The "L.E.R. Cãofiante" project is an Animal Assisted Reading project implemented by the Silves Municipal Library in 2015 (BMS, 2016) as part of the support for its education community through the "Ler + Feliz" ("Happier Reading") programme. Its goal was to promote children's reading skills and motivation and to include books and reading in the daily practices in the classroom as well as in the family context, simultaneously offering a positive experience related to the library, books and reading, through a human-animal partnership which had dogs as "alternative", attentive and involved listeners.

In order to achieve its goals, the "L.E.R. Cãofiante" project divided its procedure into two different typologies of intervention, internationally determined by the International Association of Human-Animal Interaction Organisations (IAHAIO, 2014): one component of Animal Assisted Education, through the development of a programme to help children in small groups to overcome difficulties with reading skills; and one component of Animal Assisted Activity, through the animation of monthly sessions of book and reading mediation in the library, with the assistance of the project's dogs, for two first-grade classes. The 
data presented here concern only the Animal Assisted Activity component.

The Animal Assisted Reading intervention was carried out with two classes, one of which participated in seven monthly sessions and the other eight, throughout the 2015-2016 school year. This component of the project intended to motivate pupils in both classes to read by creating more reading opportunities in the classroom as well as in a family environment; by guaranteeing access to books which met the children's preferences, reading levels and age groups; by modelling reading strategies; and by creating attentive and participative listeners. Sessions lasted one hour and 15 minutes, divided into various moments: 1. arrival of the children to the library and return of the books borrowed the previous month; 2 . admission into the room dedicated to the sessions, welcomed by the project librarian and her dogs; 3 . dialogue concerning the readings made at school and at home and free expression of opinions that the books and reading may have aroused in the children; 4. reading of one or two books by the librarian in the presence of the dogs (as the children learned to read, so they also started reading to the dogs, at times stories which they wrote themselves); 5 . individual presentation of each of the 25 books for the next month, in such a way as to arouse curiosity and interest in their reading; 6 . free interaction in which each pupil had the opportunity to make first contact with the books and even read small excerpts voluntarily to the dogs; and 7. conclusion, with each pupil carrying a book on the way to school. In addition to these sessions in the library, the teachers would provide moments for reading in the classroom and promote weekly loans of books for reading at home with the families, and the children would register on their reading notebooks the books they read and their opinions on them.

\section{Participants}

The participants were pupils in four first-grade classes, a total of 80 children divided into two groups according to the manner of their participation: the Intervention Group (47 children), which was composed of the pupils in the two classes that participated in the sessions at the library, and the Comparison Group (33 children), which was composed of two classes that did not participate in the project. The ages of the children, at the beginning of the project, varied between five years and 10 months, and six years and 11 months; $43(53.6 \%)$ were boys and $37(46.3 \%)$ were girls. The parents, who were mostly educated to a ninth-grade level or higher $(90.1 \%)$, also participated along with the two teachers of the classes involved.

\section{Instruments}

For gathering data from the children, a scale was used that was adapted from the Achievement Emotions Questionnaire - Elementary School (Pekrun, Lichtenfeld, Killi, \& Reiss, 2007) which, in its original version, focused on emotions associated with the learning of mathematics. The items were adjusted to reading situations. They were presented to the children as statements which were read aloud, and the answer scale was pictorial, a sequence of five faces with different expressions which gradually became more identifiable as the emotion they referred to. Thus, the sequences of facial expressions were different for the three emotions in question, with different versions for boys or girls as well. In the factorial analysis carried out, the three-dimensional structure was clear and consistent with the original one, showing altogether an explained variance percentage of $63.29 \%$ and adequate values of internal consistency (Hair, William, Barry, Rolph, \& Ronald, 2010) which varied between .80 and .83 (Table 1). The scale was thus composed of 13 items, considering three emotions: enjoyment (e.g. "I like reading"), boredom (e.g. "I think reading is so boring that all I want is to stop") and anxiety (e.g. "When I have to read aloud I get nervous").

With regard to the parents, a questionnaire was developed which was composed of open-ended questions in order to characterise the way their children shared the experiences they had with the project at home and the way the families had integrated and experienced reading in their lives. One other questionnaire was developed for the teachers, also composed of open-ended questions, with the goal of gathering their opinions on the execution of the project and its impact on class routine, children's skills and family involvement.

\section{Procedures}

In order to gather data from the Intervention Group, the project coordinator asked the municipality, the schools and the parents for the necessary authorisations. For the Comparison Group, permission was asked from the schools, the teachers and the parents. Data from the children were gathered in small groups (three to four children), over periods of 15 to $20 \mathrm{~min}$ utes, on two occasions: the beginning of the school year, November and the end of the school year, May. 
Table 1.

Factorial Analysis of the Emotion Scale and Internal Consistency Values

\begin{tabular}{lccc}
\hline & & Factor & 3 \\
\cline { 2 - 4 } & 1 & 2 & \\
\hline Emo4_Enjoyment & .814 & & \\
Emo7_Enjoyment & .749 & \\
Emo1_Enjoyment & .742 & \\
Emo13_Enjoyment & .712 & & \\
Emo10_Enjoyment & .699 & .829 & \\
Emo9_Boredom & & .747 & .742 \\
Emo12_Boredom & & .676 & .845 \\
Emo6_Boredom & & & .768 \\
Emo3_Boredom & & & .748 \\
Emo5_Anxiety & & & .638 \\
Emo2_Anxiety & & & 1.09 \\
Emo8_Anxiety & & 2.37 & 8.41 \\
Emo11_Anxiety & 4.76 & 18.26 & .80 \\
Eigenvalue & 36.62 & .83 & \\
Explained variance & .81 & & \\
Cronbach's alpha & & & \\
\hline
\end{tabular}

The division into small groups aimed at making sure the answers of some were not influenced by those of others, that the instructions were well-understood and the answers noted. Each sentence was read aloud and each child was asked to choose the image that better represented the way they felt towards the situation described. At first, the children answered a few questions in order to acquaint themselves with the scale's format.

Data concerning parents and teachers were gathered at the end of the school year, through individual questionnaires delivered by the project coordinator and later answered at home and returned on an agreed-upon date. These were designed in such a way as to be simple and not too time-consuming, in order to encourage the participation of both families and professionals.

For statistical processing of the gathered data, the SPSS Statistics software (IBM SPSS Statistics V22.0, 2016) was used.

\section{Results}

\section{Scale of Emotional Responses to Reading}

Regarding emotions, this study analysed enjoyment, anxiety and boredom towards reading. These emotions were characterised at the beginning and end of the project, which coincided with the initial and final periods of the school year. In addition to the Intervention Group, data were also gathered from two other classes which were used as the Comparison Group and which did not participate in the project. The graph in Figure 1 shows the values of perceived enjoyment as gathered from the children in both groups at the beginning and end of the year.

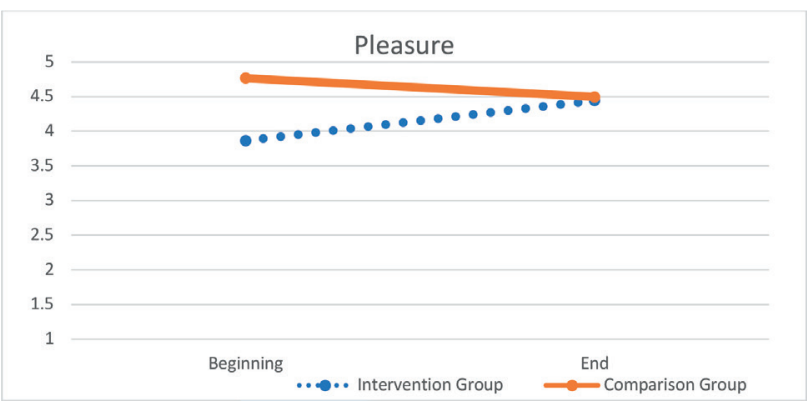

Figure 1. Pleasure when reading at the beginning and end of the school year. 
One can observe that the average in the Intervention Group was at first lower than that of the Comparison Group, which was very close to the maximum value. The graph (Figure 1) shows that, while in the Comparison Group the perceived enjoyment from reading decreases, it increases instead in the Intervention Group, obtaining similar values at the end.

As for anxiety, the graph in Figure 2 shows that, at first, the values in both groups were not very high, indicating low levels of anxiety, as they were both located beneath the midpoint of the scale (3). However, these were higher for the Intervention Group than they were for the Comparison Group. One can note that these values were kept low up to the end of the year, even slightly decreasing among children in the Intervention Group.

Finally, the graph in Figure 3 illustrates what happened regarding boredom towards reading throughout

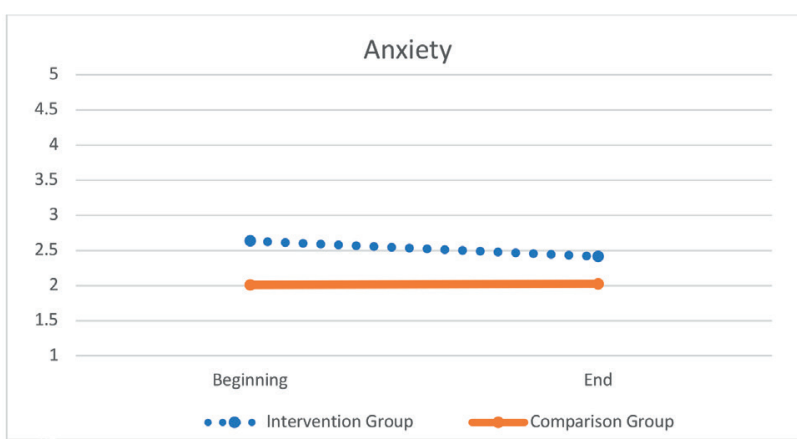

Figure 2. Anxiety when reading at the beginning and end of the school year.

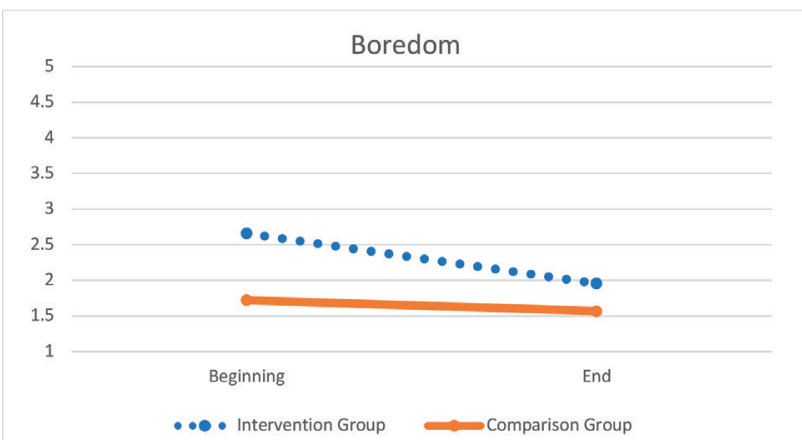

Figure 3. Boredom when reading at the beginning and end of the school year. the year in both groups. A reading of the graph shows us that, initially, the average in the Intervention Group was higher than the Comparison Group, close to the midpoint of the scale. The average values concerning boredom decrease in both groups from the beginning until the end of the year, but that decrease is more pronounced among children in the Intervention Group.

In order to verify if these distinct emotional patterns were significantly different throughout the year, we resorted to a repeated measures ANOVA, taking into account the initial and final differences between both groups. A global effect was identified for emotional responses to reading in the interaction between the moment (beginning and end) and the group (intervention and comparison) [Pillai's Trace $=.135, F(3,72)$ $=3.75, p=.015]$. The univariate analyses later performed showed that this effect was meaningful for enjoyment alone $[F(1,74)=11.10, p=.001]$.

\section{Participation in the "L.E.R. Cãofiante" Project}

The analysis conducted of the parents' answers to the questionnaire allowed us to notice that references to positive emotions such as joy, enthusiasm and satisfaction were present in many descriptions of the way their children experienced the "L.E.R. Cãofiante" project:

\footnotetext{
"She loved the project, there was never a day that she didn't come home from the project happy" (P12).

"With a lot of enthusiasm, and it always ended with the same question: Will it be long before we go to the library again?"” (P38).

"Those were moments of pleasure, which echoed at home with the books she brought with her" (P1).

"He talked about the project with a lot of joy, because be loves animals and stories" (P24).

"Very happy and satisfied when she talked about what they read and the stories she was told" (P19).

"With a lot of enthusiasm. I can even say, with absolute certainty, that he loved every moment of it" (P22).
}

The teachers also noticed positive emotional differences in their students, with benefits for their academic lives and for the bonds created between the children and the animals:

\footnotetext{
'The dogs' presence has been beneficial, because the students loved their interactions with them, and were always interested in reading to MoMo and Pipa, as well as performing many tasks for them" (D1).
} 
"There were benefits in the dogs' presence in the sessions because the interaction with MoMo and Pipa stimulated learning, the will to read and perform tasks for them, it also contributed to tighten affective ties [between] pupils [and] dogs" (D2).

At the end of the school year, when the children were asked about the project, they did not hesitate and almost unanimously declared feeling happy with their participation in it $(95.7 \%)$, and even the remaining ones mentioned feeling good, none of them expressing any negative opinions. Furthermore, all stated their desire to see the "L.E.R. Cãofiante" project continue the following year.

\section{Discussion of Results}

In order to analyse the effects on emotional responses to reading in the children that participated in the project, three different emotions were studied - enjoyment, anxiety and boredom - and the global effects of the intervention were approached by taking into consideration both moments (beginning and end) and groups (intervention and comparison).

In regard to enjoyment, the values obtained from the Comparison Group decreased as the year progressed, in conformity with the data that Monteiro and Mata (2001) gathered when they compared enjoyment of reading between different grades, noticing a significant decrease which has also been noticed in learning in general (Pekrun, 2009, 2014). However, enjoyment values increased in the Intervention Group, showing benefits for the children in it. These results are also in line with other studies on the benefits of the presence and participation of dogs in children's motivation, explained by the comforting and non-judgemental presence of a dog (Friesen \& Deslile, 2012; Hall, Gee, \& Mills, 2016; Jalongo, 2005). The programme thus appears to compensate the decrease in enjoyment from reading usually associated, in literature, with progress in educational levels, and which was evident in the Comparison Group (Monteiro \& Mata, 2001; Pekrun, 2014).

With respect to anxiety, the Intervention Group initially had higher levels and, as proposed by Hall et al., (2016), these values lowered. In the Comparison Group, they remained relatively stable. However, when comparing both groups, the difference between them was not statistically meaningful. This can be explained by the initially low levels of anxiety in both groups (they were both located below the midpoint of the scale), as is usual in this age range (Pekrun, 2009), which is why the effects of the project may not be so noticeable. This way, even if there are slight differences, these are not meaningful enough during the period of the intervention. Since the studies related by Hall et al., (2016) in which significant differences were shown were developed with older pupils, that may well be the reason for the absence of differences in this work with first graders, as anxiety levels are usually higher among older pupils (Pekrun, 2014). An intervention which spanned over a longer period of time could eventually lead to more accentuated differences between the groups.

Concerning boredom while reading, the Intervention Group showed higher levels in the beginning, though these were below the midpoint of the scale, and some decrease was seen throughout the year. The Comparison Group initially had lower levels of boredom, which remained relatively stable with time. However, although these patterns were different, they were not statistically significant. Probably, if the programme lasted longer or the visits to the library were more frequent, the differences between these profiles would have been more evident and the impact of the programme more accentuated. It is known that children's motivations are more intrinsic as they first start going to school and become more extrinsic as they progress (Monteiro \& Mata, 2001), eventually becoming associated with more negative emotions. Thus, it may be important to study the way in which a programme such as this may have beneficial effects on negative emotions of pupils in different grades.

The identification of the effects of this project on children's positive emotions in relation to Fredrickson's (2003, 2004, 2013) broaden-and-build theory appears to have a global importance. Within this theoretical framework, Fredrickson specifies the role of positive emotions when she mentions that these may not only broaden the subject's attention and resources, but also support the building of new resources at different levels (physical, social, psychological, intellectual). Taking these ideas into account when specifically considering reading, we have noted that enjoyment from reading increased among children in the "L.E.R. Cãofiante" project. However, it was not only from the questionnaires on emotions that the children answered that their positive emotions became evident. The reports from parents and teachers are consistent in mentioning pleasure, satisfaction, joy, desire to repeat the activities, etc., which were not limited to the time spent in the library but were apparent later at home and in school. The positive 
experiences they had may be helpful both in the discovery of the functions and uses of written language and in acquiring pleasure in reading. Furthermore, it may also contribute to the development of various resources, as Fredrickson $(2003,2004,2013)$ predicts, which in this case may revolve around resilience along with decoding and comprehension skills, which in turn lead to the acquisition of increasingly complex skills related to reading. Resilience, dedication and effort resulting from the positive moments experienced appear clearly in the reports from the teachers, namely when they mention that: "they were always interested in reading for MoMo and Pipa, as well as performing many tasks for them" or "interaction with MoMo and Pipa stimulated learning, the will to read and perform tasks for them, it also contributed to tighten affective ties...".

Furthermore, the feeling of being capable developed in parallel, which resulted in children spontaneously reading to their classmates when they went to the library and expressing desire to share tastes, experiences and readings, which was also strongly encouraged by the librarian in the monthly sessions. The dogs also played an important part in these sessions, as they not only supported the children in choosing their books but would also patiently "listen" to their readings, barking at the end of the readings, participating in the stories with their abilities (e.g. signalling characters, ringing a bell), or simply being present and allowing themselves to be petted. Thus, they made these moments safer and more supportive without losing playfulness, offering the children meaningful and affectively positive experiences which, as Friesen and Deslile (2012) state, are central elements for understanding the value of this type of intervention.

\section{Final Remarks}

This work made it possible to confirm the positive effect of an intervention for the promotion of reading as part of what is characterised as an Animal Assisted Activity. It has been shown that the children who participated in this activity, compared to those who did not, had significant benefits in terms of enjoyment of reading at the end of the intervention. These data were corroborated by the testimonies of parents and teachers alike, where no mention was found of negative effects, and mentions of positive experiences stood out which encouraged children to continue and created the desire to participate in new activities. However, the intervention only spanned one school year, making it uncertain whether the effects noted would increase or stagnate over a longer period of time. It is also doubtful whether these benefits will be maintained after the end of the intervention. These aspects may be explored in future investigations.

\section{References}

American Veterinary Medical Association (AVMA). (2016). The buman-animal interaction and human-animal bond. Aug 15 2016. https://www.avma.org/KB/ Policies/Pages/The-Human-Animal-Bond.aspx

Beetz, A. (2013). Socio-emotional correlates of a schooldog-teacher-team in the classroom. Frontiers in Psychology, 4. doi: 10.3389/fpsyg.2013.00886.

Beetz, A., \& McCardle, P. (2017). Does reading to a dog affect reading skills? In N. Gee, A. Fine, \& P. McCardle (Eds). How animals help students learn: Research and practice for educators and mental-health professionals (pp. 111-123). New York: Routledge.

BMS- Biblioteca Municipal de Silves (Silves Municipal Library) (2016). Educação assistida por animais - Projeto L.E.R. Cãofiante. $2^{a}$ Conferência Internacional de Intervenções Assistidas por Animais (Animal assisted education - the L.E.R. Cãofiante project. 2nd International Conference on Animal Assisted Interventions), Cascais.

Fine, A. H., \& Beck, A. M. (2010). Understanding our Kinship with animals: input for health care professionals interested in the human/animal bond. In A. H. Fine (Ed.), Handbook on animal-assisted therapy. Foundations and guidelines for animal-assisted interventions (3rd ed., pp. 3-15). Elsevier Inc. doi:10.1016/ B978-0-12-381453-1.10001-7

Fredrickson, B. L. (2003). The value of positive emotions. The emerging science of positive psychology is coming to understand why it's good to feel good. American Scientist, 91, 330-335.

Fredrickson, B. L. (2004). The broaden-and-build theory of positive emotions. Philosophical Transactions of the Royal Society: Biological Sciences, 359, 1367-1377. doi: 10.1098/rstb.2004.1512

Fredrickson, B. (2013). Positive emotions broaden and build. In P. Devine \& A. Plant (Eds) Advances in Experimental Psychology (Vol. 47, pp. 1-53). Burlington: Academic Press. doi: 10.1016/ B978-0-12-407236-7.00001-2 
Fredrickson, B., \& Joiner, T. (2002). Positive emotions trigger upward spirals toward emotional well-being. Psychological Science, 12, 191-220. doi: 10.1111/1467-9280.00431

Fredrickson, B., \& Joiner, T. (2018). Reflections on positive emotions and upward spirals. Perspectives on Psychological Sciences, 13(2), 194-199. doi: 10.1177/1745691617692106

Friesen, L. (2009). Exploring animal-assisted programs with children in school and therapeutic contexts. Early Childhood Education Journal, 37(4), 261-267. doi: 10.1007/s10643-009-0349-5

Friesen, L., \& Delisle, E. (2012) Animal-Assisted Literacy: A Supportive environment for Constrained and Unconstrained Learning, Childhood Education, 88(2), 102-107. doi: 10.1080/00094056.2012.662124

Froiland, J., \& Oros, E. (2013) Intrinsic motivation, perceived competence and classroom engagement as longitudinal predictors of adolescent reading achievement. Educational Psychology, 34(2),119-132. doi: 10.1080/01443410.2013.822964

Hair, J. F., William, C. B., Barry, J. B., Rolph, E.A., \& Ronald, L. T. (2010). Multivariate data analysis (7th ed.). New Jersey: Pearson Education.

Hall, S. S., Gee, N. R., \& Mills, D. S. (2016). Children reading to dogs: A systematic review of the literature. PLOS ONE, 11(2), 1-22.doi:10.1371/journal. pone.0149759

IAHAIO (2014). The IAHAIO definitions for animal assisted intervention and animal assisted activity and guidelines for wellness of animals involved. http://iahaio.org/ wp/wp-content/uploads/2017/05/iahaio-whitepaper-final-nov-24-2014.pdf

Jalongo, M. R. (2005). "What are all these dogs doing at school?": Using therapy dogs to promote children's reading practice. Childhood Education, 81(3), 152-158. doi: 10.1080/00094056.2005.10522259

Kirnan, J., Siminerio, \&, Wong, Z. (2016) The impact of a therapy dog program on children's reading skills and attitudes toward reading. Early Childhood Education Journal, 44(6), 637-651. doi: 10.1007/ s10643-015-0747-9

Mills, D., Hall, S. (2014). Animal-assited interventions: Making better use of the human-animal bond. Veterinary Record, 174(11), 269-273. doi: 10.1136/ vr.g1929

Psico-USF, Bragança Paulista, v. 25, n. 2, p. 321-330, abr./jun. 2020
Monteiro, V., \& Mata, L. (2001). Motivação para a leitura em crianças do $1^{\circ}, 2^{\circ}, 3^{\circ}$ e $4^{\circ}$ anos de escolaridade (Motivation for reading in children in the 1st, 2nd, 3 rd and 4th grades). Infância e Educação - Investigaçao e Práticas, 3, 49-68.

Nepps, P., Stewart, C., \& Bruckno, S. (2014). Animalassisted activity: Effects of acomplementary intervention program on psychological and physiological variables. Journal of Evidence-Based Complementary \& Alternative Medicine, 19(3), 211215. doi: $10.1177 / 2156587214533570$

Odendaal, J. S. J. (2000). Animal-assisted therapy - Magic or medicine? Journal of Psychosomatic Research, 49(4), 275-280. doi:10.1016/S0022-3999(00)00183-5

Pekrun, R. (2013). Emotions, motivation, and self-regulation: Common principles and future directions. In N. Hall, \& T. Goetz (Eds.), Emotions, motivation, and self-regulation: $A$ handbook for teachers (pp. $167-$ 188). Bingley: Emerald Group Publishing Limited.

Pekrun, R. (2009). Emotions at School. In K. Wentzel \& A. Wigfield (Eds.), Handbook of motivation at school (pp. 575-604). New York: Rotledge.

Pekrun, R. (2014). Achievement emotions. In M. Furlong, R. Gilman \& E.S. Huebner (Eds.), Handbook of positive psychology in schools. (pp. 146-164) New York: Rotledge.

Pekrun, R., Lichtenfeld, S., Killi, U., \& Reiss, K. (2007). Achievement emotions questionnaire - Elementary school (AEQ-Elementary School) - User's manual. Munich, Germany: University of Munich, Department of Psychology.

Scanlon, D., Anderson, K., \& Sweeney, J. (2017). Early intervention for reading diffculties - The interactive strategies approach. New York: The Guilford Press

Shaw, D.M. (2013). Man's best friend as a reading facilitator. The Reading Teacher, 66(5), 365-371. doi: 10.1002/TRTR.01136

Turner, W. G. (2007). The experiences of offenders in a prison canine program. Federal Probation, 71(1), $38-43$.

Wilson, C., \& Turner, D. (1998). Perspectives on animal-assisted activities and therapy. In C. Wilson \& D. Turner (Eds.), Companion animals in human health (pp. 23-39). Thousand Oaks, California: SAGE Publications.

Recebido em: 30/05/2018

Reformulado em: 28/04/2019 
Support and financing:

This project was developed with support from the Silves Municipality and the FCT (Foundation for Science and Technology) - UID/CED/04853/2016

About the authors:

Lourdes Mata is Assistant Professor in the Educational Psychology Department at ISPA - Instituto Universitário in Lisbon, Portugal. She obtained a doctorate in Child Studies at the Minho University and is a member of the CIE (Centre for Research in Education) at ISPA. Her research interests focus on the affective and motivational processes involved in teaching and learning, and family involvement in education.

ORCID: https://orcid.org/0000-0001-8645-246X

E-mail:lmata@ispa.pt

Maria José Mackaaij is Librarian at the Loulé Municipal Library in Portugal. She specialised in Documentation Sciences at the Faculty of Letters of the University of Lisbon. She teaches a course named "Animal Assisted Therapy in Reading Support Projects" in the Animal Assisted Therapy postgraduate programme at ISPA - Instituto Universitário. Her research interests focus on the affective and motivational processes related to reading in childhood.

ORCID: https://orcid.org/0000-0002-0129-8828

E-mail: mjose.mackaaij@gmail.com

Margarida Calado has a Master's degree in Educational Psychology from ISPA - Instituto Universitário. The subject of her master's thesis was "Motivation for reading and reading habits in an animal assisted reading/education program", which is one of her preferred research areas. She works as Educational Psychologist.

ORCID: https://orcid.org/0000-0003-1440-5175

E-mail: margaridasilvacalado@gmail.com

Contact:

Lourdes Mata

ISPA - Instituto Universitário, Jardim do Tabaco Street, n. 34, 1140-041 LISBON

Phone number: 00351218811700 